\title{
ANALYSIS OF FACTORS THAT AFFECTING THE INTEREST OF CUSTOMERS BCA BANK TO USE KLIK-BCA (CASE STUDY: BCA BANK KCP KALIMALANG, BEKASI)
}

\author{
Ichwan Mochammad Buchori $^{1}$, Purwanto ${ }^{1}$ \\ ${ }^{1}$ Faculty of Business, President University, Indonesia
}

\begin{abstract}
This research has an objective to analyze the factors that affecting the interest of customers BCA bank yo use KlikBCA inKCP Kalimalang, Bekasi. BCA is the market leaader of internet banking in Indonesia with its KlikBCA. Now, the number of KlikBCA user is increasing both individual and business. Until 2009, the number of KlikBCA user increase become 1.7 million costumers from 1.2 million in 2008. The purpose of this research is to analyze the factors which have impact to the customers interest to use KlikBCA. Variables used in this this research are: independent variable (ease of use, convenience, privacy, and feature avaiability). While the dependent variable is the interest to use. The results are: ease of use and feature availability are not significant impact to the interest to use, while convenience and privacy are significant impact to the interest to use.
\end{abstract}

Keywords: KlikBCA, ease of use, convenience, trust, and feature avaiability.

\section{Introduction}

How to improve service quality and satisfying customers is one thing which is the goal for every company, both service and industrial companies. Many products has produced by various types, quality and packaging in which the whole thing is only intended to attract customers, so that customers tend to perform activities to obtain the product. Therefore, every company is required to be able to create the best products with specifications that customer satisfaction can be met.

In this current year, technology advances are already very sophisticated, it is believed to contribute substantially to the significant growth in the services sector, especially banking services. Information technology (IT) is very significant role in supporting the competitiveness of each company, for example in terms of the creation or delivery of new service, operational, for customer services, and the establishment of a centralized customer service department, and accurate marketing database development. One of use of shape IT is Internet Banking.

The presence of internet banking already making the customers of bank easily to access the services that already given from the bank itself. Internet Banking already brought a fundamental change in the type of banking services, that initially using manual techniques to self-service using a goods. Over the last few years, commercial banks have introduced Internet-based banking system to improve operations and reduce costs. Internet banking is one of many products ranging services offered by commercial banks in Indonesia. In general, the technology and the level of internet banking usage in Europe by customers is the highest (Scheider, 2004).

Internet Banking actually is the reason for most customers used for every transaction. Because the ease and usefulness, began many bank customers in Indonesia using internet banking in banking transactions. The number of Indonesian customers who use internet banking in 2001 amounted to 293351 people. This amount is then increased to 424063 
people in 2004. The total internet banking transactions in 2001 reached Rp 7.45 trillion and increased in 2004 to $\mathrm{Rp} 35.51$ trillion per year.

This is actually one of commercial bank in Indonesia already implement the use of internet banking system on banking services and the market leader in Internet banking market, it is Bank Central Asia (bank BCA). BCA is one of the biggest commercial bank Indonesia that already implement the use of internet banking system on their services. The level of use of Internet banking itself is already very high for this time and known as $K L I K$ $B C A$. Based on the Bank's annual report in 2009, recorded an increase of $20 \%$ for the number of transactions through Klik-BCA from 135 million to 162 million transactions transactions with a total transaction valued at Rp114, 6 billion. This is certainly supported by the reliability and excellence of product Klik-Bank internet banking product compared with other commercial banks.

In the MARS study conducted by Imam (2007), has been study the consumer profile of Indonesia to the percentage of the number of internet banking users to bank customers in Indonesia, which is shown in Table 1.

Table 1. Total Customer Percentage of Internet Banking Users

\begin{tabular}{|c|c|c|}
\hline No & Brand & Percentage (\%) \\
\hline 1 & Klik-BCA & $64.3 \%$ \\
\hline 2 & Internet Banking Mandiri & $9.5 \%$ \\
\hline 3 & HSBC Internet Banking & $11.9 \%$ \\
\hline 4 & Permata Net & $9.5 \%$ \\
\hline 5 & BII Internet Banking & $4.8 \%$ \\
\hline \multicolumn{2}{|c|}{ Total } & $100 \%$ \\
\hline
\end{tabular}

Source: Penelitian MARS 2007

Based on the data in table 1 above, Klik-BCA in the first ranked with a total percentage of $64.3 \%$ of the number of internet banking users, amounting to approximately $3,000,000$ people. Then HSBC is $11.9 \%$,Mandiri Banking and PermataNet internet banking of $9.5 \%$, and BII internet banking of $4.8 \%$. This shows that almost all BCA bank customers has using and become a loyal customer product services of klik-BCA.

\section{Literature Review}

\section{Self-Service Technology}

Self-service technology (SST) is an intermediate technology that allows consumers to produce their own services without relying on the company employees, for examples of services is through the internet. Meuter, et al. (2000) explained that there has been a lot of evidence of technological innovation will continue to increasingly influence consumer interaction with businesses where this interaction will be an important criterion for long-term success of the company's business. This issue is now being implemented by the developed company at this time.

This has attracted the attention of us to conduct research to determine: (1) what are the factors that lead to consumer satisfaction or dissatisfaction with service-SST, (2) is there any difference with interpersonal services, (3) how satisfied or dissatisfied are consumers perceived with respect to attribution, behavioral complaints, information by word of mouth (word-of-mouth-WOM), and intention to re-purchase. The reason companies use SST are due to several reasons, which are: (1) many forms of service are done through technology, (2) 
many companies that have used SST, (3) technology provides the ability for consumers to learn, receive information, train yourself, and provide their own services.

\section{Marketing}

The importance of a company's marketing activities undertaken to achieve the objectives of the company that trying to put marketing at the center and guide the activities of all units produced towards the achievement of corporate goals. To get the achievement of the company's it must required a marketing concept. The concept of marketing is the key to achieving organizational goals consists of determining the needs and wants of target markets and deliver the expected satisfaction more effectively and efficiently (Kotler, 1997).

According to Kotler (2001), the marketing concept consists of four things: (1) target market, (2) customer needs, (3) integrated marketing, (4) the ability to generate profits. The concept started from a well-defined market, focuses on customer needs, coordinates all the activities that will affect customers, and produces profits that satisfy customers.

\section{Consumer Behavior}

To know the consumer, it need understanding of consumer behavior that a manifestation of the whole activity of the human soul itself. According to Engel, et al. (1994), consumer behavior is an action that is directly involved in obtaining, consuming, and spent products and services, including the decision preceding and following on this action. Consumer behavior is the individual activities are directly involved in the services, including the decision-making process. There are two important elements of the meaning of consumer behavior, there is: (1) the decision-making process, (2) physical activity that involving individuals in assessing, acquiring and using economic goods and services (Swastha, 1990).

According to Kotler and Armstrong (2001), there are several factors that influence consumer behavior, which is among psychological factors. As the kinds of psychological factors, among others: (1) Motivation is a need that is sufficiently stimulated to make someone look for the satisfaction of their needs, (2) Perception is the process where someone choosing, organize, and interpret information to form a picture meaning of the world, (3) learning is the change in individual behavior that exists from experience, (4) Confidence is descriptive thinking of someone about something, and attitude describe assessments, feelings, and relatively consistent tendency of a person to an object or ideas.

\section{Internet Banking}

Internet banking that also known as"online banking or e-banking", according to wikipedia is doing transactions, payments, and other transactions via the internet with a website that owned by bank with security systems. Nowdays, many banks are provide services via internet banking. The implementation of an Internet banking application or the application of information technology that continue to develop and be used to answer the wishes of banking customers who want fast service, safe, comfortable, inexpensive and available at any time ( 24 hours / day, 7 days / week) and can be accessed from anywhere either that of HP, Computer, laptop / notebook, PDA, and so on. 


\section{Internet Banking in Indonesia}

Based on data from Bank Indonesia, customers who transact through internet banking in 2009 reached into 2.5 million, far greater than the customers in 2008 that amounted to only 1.5 million customers. Added client that automatically increase the value of Internet banking transactions. If the transaction value for the year 2008 amounting to Rp 207 billion from 79 million transaction, then in 2009, the value of transactions through internet banking increased to Rp 1.502 trillion from more than 250 million transactions (Indonesian Banking Highlights, 2009). From the data above, it can be seen that internet banking in Indonesia has increased rapidly in recent years. Table 2.2 below shows the bank in Indonesia that has internet banking facility along with the first year of the service and the address of the site:

\section{Ease of Use}

According to Davis (1989) defines ease of use as the degree to which a person believes that information technology (IT) can be easily understood. According to Goodwin (1987); Silver (1988), in Adam, et al. (1992), intensity of used and the interaction between the user (users) with the system also can show us the ease of use. The system is used more often has indicate that IT is better known, easier to operate and easier to use by users.

Based on the definition above, it can be concluded that the ease of use will reduce the effort (either time and energy) to learn someone in IT. The comparison of ease gives an indication that the people who use IT to work more easily than people who work without the use of IT (manually). IT users believe that IS (information system) is more flexible, easy to understand and easy to operateor compartible as characteristic ease of use.

Davis (1989) provide some indicators of the ease of use of IT among others, include: 1) information technology (IT) is very easy to learn. 2) IT will doing easily what is desired by the user. 3) the users skill will grow up by using IT. 4) IT is very easy to operate. Several previous studies indicate that the perception of ease of used are the main factors that influence the use of internet banking (Davis, 1989; Venkatesh and Davis, 2000; Pikkarainen, et al., 2004).

\section{Convenience}

Convenience means BCA customers feels that the Klik-BCA is flexible in terms of time and place. According to Poon (2008), Internet banking provides a higher level of comfort which allows customers to perform banking transactions anytime and anywhere. If compared with the banking transactions without using aninternet banking, for example with interpersonal transactions, internet banking provides more benefits and convenience. For example, if you want to pay bills or transfer money, when through branch office, the customer have to wait long to conduct the transactions. This is certainly give less provide convenience for customers . It is different if the transaction is done by internet banking. If you are using internet banking, the transaction is done by accessing internet banking websites (can be done with a PDA, Notebook, PC and so on) whenever and wherever the customer is located. This is surely will save customers time, especially for busy customers.

According to Poon (2008), there are some constructs which are indicators of the convenience an internet banking system, as follows: (1) Customers can access internet banking anytime, anywhere, (2) There is no queuing, (3) Saving time if compared with the conventional banking method, (4) the cost of bank interest are cheap if the customers 
perceive that the internet banking system that is convenient, so the customer will feel satisfied with the services of internet banking, then they will be interested to use it in the future. Several previous studies (Hong, et al., 2001; Fu, et al., 2003; Pikkarainen, et al., 2004; Poon, 2008) showed the results of convenience can bring a psitive influence towards intention to use internet banking.

\section{Privacy}

To be able to maintain long-term relationships with its customers, the bank needs to keep the concept of customer satisfaction. In order to survive in the era of e-banking, the bank must have loyalty customer who trust in the exelence of online services.

As the proliferation of Internet crimes such as burglary account, Privacy factor becomes very important in the use of internet banking in banking transactions. The concept of trusworthy means that customer trust in the reliability of the banks to ensure the securities and privacy of customers account. Security means that the use of Internet banking is safe, the risk of lost of data or a little bit information, and the low risk of hack. While privacy means that all matters related to the user's personal information is safe, and no third party can know.

According to Gerrard and Cunningham (2003), the dubious trustability aspects customers on security and privacy policy banks. Privacy has a significant effect on the willingness of customers to engage in online financial transactions and the provision of confidential information (such as user id and password privacy, personal accounts, etc.).

In term of used of internet banking, most of user doesn't know at all the risk and privacy from the internet banking. They just assume that the banks already noticed the security and privacy, when the users don't know how strong the security and privacy of the informaton system of internet banking. Therefore, customer confidence is an important factor that encourage customers to banking transaction.

According to Jia, Shen (undated), there are some constructs which are indicators of privacy, there are : (1) the bank's security system, (2) the system of bank secrecy, (3) security and privacy, and (4) compensation for losses due to reasons security and privacy. Several previous studies on privacy (Gefen, Karahanna, et al., 2003; Gefen and Straub, 2003; and Jia, Shen, undated), shows that privacy have a positive affect towards the intention to use internet banking.

\section{Features Availability}

Actually, feature is a special aspects, have a characteristics, special services, a variety of advantages which are integrated or brought in a product is exposed to customers, social or public. Nowdays, so many features exists in a variety of media, such as the Internet websites, smartphone, magazines, television and others. feature is a marketing system that can attract customers to buy or use the product that provided by the company.

According Ainscough and Luckett (2000), the equipment for customer interactivity is an important criterion that attract the attention of customers in the delivery of internet banking services. Gerrard and Cunningham (2003) also identified another important factor in the success of internet banking is the ability of innovation to face the needs of customers using feature availability are different on the website. Features is mean things what can be done by customers using internet banking.

According to Poon (2008), there are some constructs which are indicators of the availability of features an internet banking system, such as: the ease of access to information 
about products and services, the diversity transaction services, the diversity of features, and product innovation.

\section{Figure 2. Theoretical Framework}

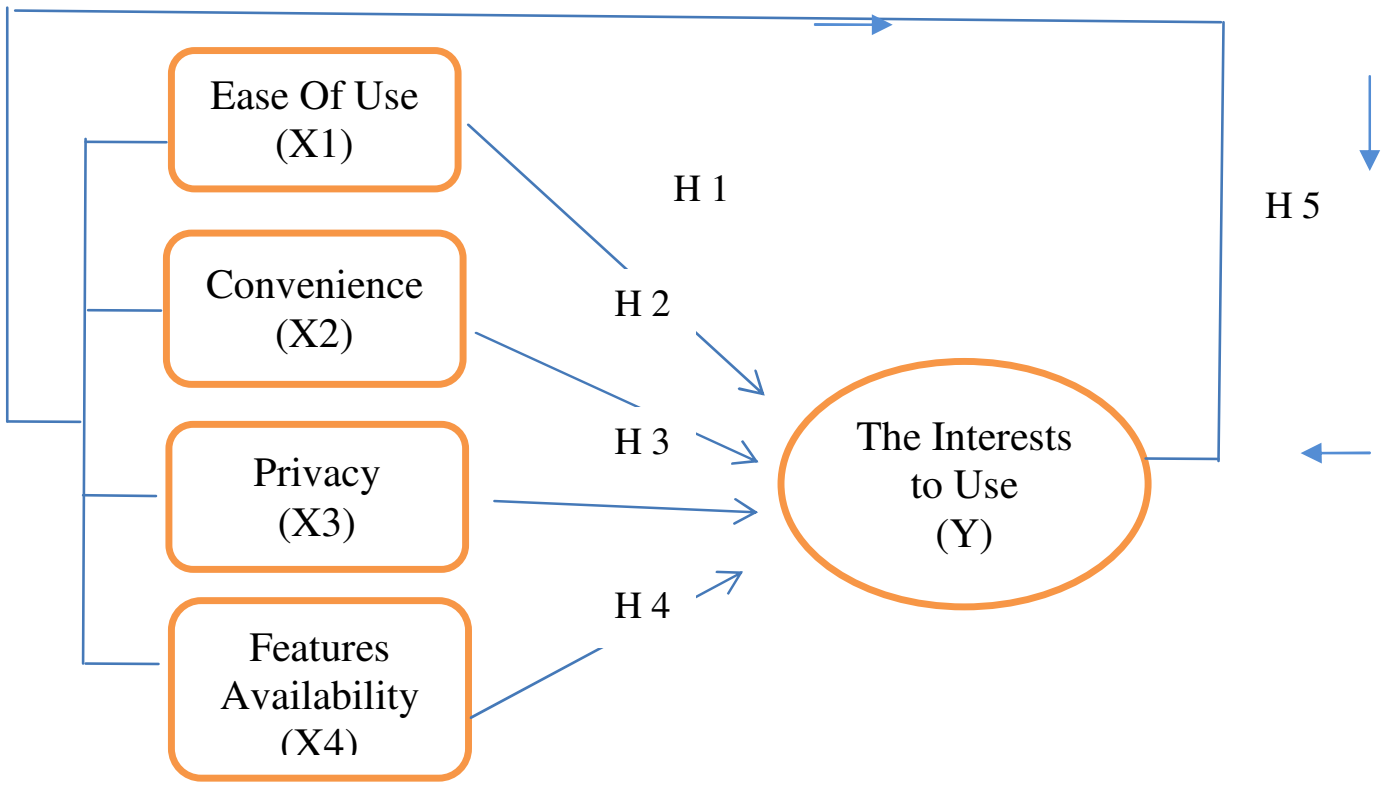

Source: Adjusted by researcher based on Sauca Ananda (2011)

\section{Methodology}

A sample is a part of the population that is selected by carefully in order to represent the population (Sugiyono, 2003). Therefore samples drawn from the population should be representative population. In this study required a minimum number of respondents by the researcher is 80 respondents. Based on the level of difficulty in finding respondent of the user internet banking, the number of respondents is required as well as the limited time owned, so the samples of this study are all banking customers using internet banking services in the Kalimalang. Customers who become in this sample is not restricted how long been using internet banking, because in this study contained respondents expect get the customers who have been long using internet banking also a new user who using internet banking, so it can be obtained describe the variability of the data in the customer's decision to continue using internet banking in the future or not.

\section{Validity Test}

Validity is important to measure whetjer the test measures what the researcher actually wished to measure (Cooper \& Schindler,2006). The Researcher used Pearson's Correlation to the test validity of the instruments being used. Validity test is done by correlating the score of each variable or each questions with the total score. If the variables have the maximum score, the variable is valid. And the researcher will test the validity of the Analysis of ease to use, convenienve, privacy and also feature availability. In Pearson correlations, results are between -1 and 1 . A result of -1 means that there is a perfect negative correlation between the two values at all, while a result of 1 means that there is a perfect positive correlation. Most research will very rarely get a correlation $0,-1$ or 1 . Result would 
be somewhere in between. The closer the value of $r$ gets to zero, the greater the variation the data points are around the line of best fit.

\section{Reliability Test}

Reliability test is important to measure whether test supplies consistent result (Cooper $\&$ Shiner,2006) . The researcher used Cronbach alpha in explanatory research for reliability. And the researcher will test the reliability of the expectation and perception of the 4 dimensions such as ease to use, convenienve, privacy and also feature availability. The rating of questionnaire used five Likert Scale where analysis of the data will be scores. The participant is asked very poor, poor, fair, good, and excellent with each statement. And a scale value 1 for very poor, 2 for poor, 3 for fair, 4 for good and 5 for excellent.

Each score of that 5 dimension will be measure into variable test to know whether the each question is reliable or not using the Cronbach Alpha Formula. The Cronbach's Alpha formula is as follows (Lind, Marchal and Mason, 2002):

\section{Classical Assumption Test}

\section{1) Normality Test}

Normality test aim to test the regression model the dependent and independent variables have a normal distribution or not. All researchers want the test will be good and a normality test called good if the data distributed normally or close to normal and also this test can uses the graphic analysis and statistical analysis. The test determined looking for the spread of dots on the diagonal line. If the data spread around following the diagonal lines its mean the test is normality, if the data spread away from diagonal line, it means the regression is rejected or do not meet the assumption of normality said Ghozali, 2005.

\section{2) Multicolinearity Test}

According to Ghozali (2005), the multicollinearity test aims to test whether the regression model found the correlation inter independent variables, it supposed to be the test there is no correlation with the independent variables. To detect the positive or negative evidence of multicollinearity in the regression model is by analyzing the correlation matrix of independent variables. This test can be seen from tolerance value or variance inflation factor (VIF). As a basis of reference it can be concluded (Ghozali, 2006):

a. If the tolerance values $>0,1$ and VIF value $<10$, it can be conclude that, there is no multicollinearity among the independent variables in the regression model.

b. If tolerance value $<0,1$ and VIF value $>10$, it can be conclude that, there is any multicolliearity among the independent variables in the regression model.

\section{3) Heterodasticity Test}

The possible existence of heterodasticity is major concern in the application of regression analysis, including the analysis of variance, because the presence of heterodasticity can invalidate statistical test of significance that assume the effect and residual (error) variance and uncorrelated and normlly distributed. A good regression model if there 
are not homoscedasticity and heterodasticity. (Lawrence, Glenn, and Guarino). Heterosdecascity can be identified if there is a specific pattern like dot which a regular pattern and also to detect the negative heteroscedascity, it can be shown if there is no clear pattern and the dot spread above and bellow the zero on the $\mathrm{Y}$ axis.

\section{Testing the Hypotheses}

\section{Multiple Regression Analysis}

In this study, researcher uses the multiple regressions to analyzing the ease of use, convenience, privacy and feature availability toward the interests of use KlikBCA. This research aim to find out how far the dependent variable can be affected to the independent variables.

\section{T-Test}

The T-Test will analyze the partial relationship between of each independent variables (coefficient $\alpha=0.05$ ) and the dependent variable. (Supranto, 2004)

1. $\mathrm{H} 01: \beta 1=0$ or if significant $<\alpha, \mathrm{H} 0$ accept

(Ease of Use has no relationship toward the interests to use)

$\mathrm{H} \alpha 1: \beta 1 \neq 0$ or if significant $<\alpha, \mathrm{H} 0$ accept

(Ease of Use has relationship toward the interests to use)

2. $\mathrm{H} 02: \beta 2=0$ or if significant $<\alpha, \mathrm{H} 0$ accept

(Convenience has no relationship toward the interests to use)

$\mathrm{H} \alpha 2: \beta 2 \neq 0$ or if significant $<\alpha, \mathrm{H} 0$ accept

(Convenience has relationship toward the interests to use)

3. $\mathrm{H} 03: \beta 3=0$ or if significant $<\alpha, \mathrm{H} 0$ accept

(Privacy has no relationship toward the interests to use)

$\mathrm{H} \alpha 3: \beta 3 \neq 0$ or if significant $<\alpha, \mathrm{H} 0$ accept

(Privacy has relationship toward the interests to use)

4. $\mathrm{H} 04: \beta 4=0$ or if significant $<\alpha, \mathrm{H} 0$ accept

(Feature availability has no relationship toward the interests to use)

$\mathrm{H} \alpha 4: \beta 4 \neq 0$ or if significant $<\alpha, \mathrm{H} 0$ accept

(Feature availability has relationship toward the interests to use)

\section{F-Test}

For the F-test is the test to support the researcher to see the entirely affecting of the independent variables with the dependent variables. The standard significant level of this test is $5 \%$ or $\alpha=0.05$ and $\mathrm{f}$-test can be calculated following this formula based on Gujarati, 2003:

Equation 3.3 F-Test

$$
f_{\text {count }}=\frac{R^{2} /(k-1)}{\left(1-R^{2}\right) / N-K}
$$


Where:

$\mathrm{R}^{2}=$ Coefficient determination

$\mathrm{K}=$ The number of coefficient regression

$\mathrm{N}=$ The number of sample

a. $\mathrm{H}_{0}: \beta 1=\beta 2=\beta 3=\beta 4=0$ or if significant $\mathrm{F}>\alpha$, accept $\beta 0$

b. $\mathrm{H} \alpha$ : at least there is no one $\beta 1 \neq 0$, if significant $\mathrm{F}<\alpha$, reject $\mathrm{H}_{0}$.

\section{Multiple Linear Regression}

Researcher tested this instrument by testing the multiple regression models, the regression used for generalizing functional relationship between variable the interests to use KlikBCA, explained in the following this formula:

\section{Equation 3.4 Multiple Regression Formula}

$$
\boldsymbol{Y}=\beta 0+\beta 1 . X 1+\beta 2 . X 2+\beta 3 . X 3+\beta 4 . X 4+\epsilon
$$

\section{Regression Coefficient Test $\left(\mathbf{R}^{2}\right)$}

According to Priyanto (2008), regression coefficient test is aim to measure the ability how much the percentage variance of independent variable in multiple regression model in explaining the variance of dependent variable. The calculation of determination coefficient value is formulated as follows (Gujarati, 1999):

$$
R^{2}=E S S=1
$$

$\mathrm{R}^{2}=$ approaching $1(100 \%)$ it means, the ability independent variables provide almost all needed information to predict the variance of dependent variable.

\section{Result and Discussion}

\section{Testing Model (F-Test)}

F-Test is conducted to determine the effect of the independent variables with the dependent variable simultaneously. 
Table 2. F-Test

ANOVA $^{b}$

\begin{tabular}{|ll|r|r|r|r|r|}
\hline \multicolumn{1}{|l|}{ Model } & \multicolumn{1}{|c|}{$\begin{array}{c}\text { Sum of } \\
\text { Squares }\end{array}$} & df & Mean Square & F & Sig. \\
\hline 1 & Regression & 2.992 & 4 & .748 & 3.233 & $.017^{\mathrm{a}}$ \\
& Residual & 17.351 & 75 & .231 & & \\
Total & 20.343 & 79 & & & \\
\hline
\end{tabular}

a. Predictors: (Constant), ease of use, convenience, privacy, feature availability

b. Dependent Variable: interest to use

Source: Statistical Product Solution and Solution Services (SPSS) v 16

Based on the table above, researcher obtained the result indicate of significant value is 0.017 which is smaller than the $=0.05$ or $5 \%$. So, it can be concluded that the variable ease of use, convenience, privacy and feature availability significantly affect the interest to use.

\section{Testing Coefficient (T-Test)}

T-Test is conducted to look the relationship of each independent variable. To test whether each independent variables significantly affects to dependent variable with the $\alpha=$ 0.05

Table 3. T-Test

\section{Coefficients $^{\mathrm{a}}$}

\begin{tabular}{|c|c|c|c|c|c|c|}
\hline \multirow{2}{*}{\multicolumn{2}{|c|}{ Model }} & \multicolumn{2}{|c|}{ Unstandardized Coefficients } & \multirow{2}{*}{$\begin{array}{c}\text { Standardized } \\
\text { Coefficients }\end{array}$} & \multirow[b]{2}{*}{$\mathrm{t}$} & \multirow[b]{2}{*}{ Sig. } \\
\hline & & $\mathrm{B}$ & Std. Error & & & \\
\hline \multirow[t]{5}{*}{1} & (Constant) & 2.990 & .729 & & 4.103 & .000 \\
\hline & Ease of use & .101 & .091 & .119 & 1.103 & .273 \\
\hline & $\begin{array}{l}\text { Convenienc } \\
\mathrm{e}\end{array}$ & .301 & .117 & .276 & 2.566 & .012 \\
\hline & Privacy & -.107 & .052 & -.219 & -2.039 & .045 \\
\hline & $\begin{array}{l}\text { Feature } \\
\text { Availability }\end{array}$ & -.005 & .092 & -.006 & -.059 & .953 \\
\hline
\end{tabular}

a. Dependent Variable: i

Source: Statistical Product Solution and Solution Services (SPSS) v 16

For the Ease of Use obtained the test statistic $t=1.103$ with the significant is 0.273. Coefficient of ease of use $t$ test result indicate the significant level of 0.273 which is higher than 0.05 or $<5 \%$. It means there is no significant relationship between ease of use and the 
interests to use and can be concluded that there is evidence to reject H0. Alternate hypothesis is reject.

For the Convenience obtained the test statistic $t=2.566$ with the significant value is 0.012. Due to the coefficient of convenience, $t$ result indicate the significant level of 0.012 which is smaller than 0.05 or $5 \%$. So, it means there is significant relationship between convenience and the interests to use. It can be concluded that there is evidence to reject $\mathrm{HO}$ and accepted $\mathrm{H} 1$.

Privacy got the $t$ tes statistic $t=-2.039$ and has significant value 0.045 . Due to the coefficient of privacy, $t$ result indicate the significant level of 0.045 which is smaller than 0.05 or $5 \%$. it means that there is significant relationship between the interests to use. It can be concluded that there is evidence to reject $\mathrm{H} 0$ and accepted H1. From the table above, for thefeature availability has got the $t$ test statistic -0.059 and has significant value higher than 0.05 or $5 \%$ is 0.953 . So, $\mathrm{H} 1$ is reject and it can be conclude that feature availability has negative or no significant influence to the interests to use.

\section{Coefficient of Determine Test $\left(\mathbf{R}^{2}\right)$}

The coefficient of determine test is measure how far the contribution of independent variables to dependent variable. The higher of $\mathrm{R}^{2}$ will be better for the study, because the independent variables more capable to explain the dependent variable. There is the value of $\mathrm{R}^{2}$ in this test based on calculation using SPSS.

Table 4. Coefficient of Determine Test $\left(\mathbf{R}^{2}\right)$ Model Summary ${ }^{b}$

\begin{tabular}{|c|c|c|c|c|}
\hline Model & $\mathrm{R}$ & R Square & $\begin{array}{c}\text { Adjusted R } \\
\text { Square }\end{array}$ & $\begin{array}{c}\text { Std. Error of } \\
\text { the Estimate }\end{array}$ \\
\hline 1 & $.884^{\mathrm{a}}$ & .747 & .602 & 3.48098 \\
\hline
\end{tabular}

a. Predictors: (Constant), f, e, p, c

b. Dependent Variable: i

From the table above, it can be seen the value of $\mathrm{R}^{2}$ is 0.747 . its means the indicate of $74.70 \%$ the interests to use have influence to four independent variables. While remaining $25.30 \%$ have influenced by other factors outside this research method, such as efficiency, fulfillment, trust and reliability.

\section{Multiple Regression Result}

In this research, regression model was used to analyze the significant effect from independent variables towards depandent variable. Regression model was to explain the causes and effects from independent variable by looking the value of standardized coefficient beta from each independent variable.

$Y=0.119 X 1+0.276 X 2-0.219 X 3-0.006 X 4$ 


\section{Interpretation of the Result}

\section{Ease of Use}

Based on the result of this research indicates that the variable of ease of use has no significant influence to The interests to use. From the T-Test, the significant value of integration is 0.273 which is higher than $\alpha=0.05$. The explanation of no significance of this variable is that the difference ease of use from all BCA customer in area Kalimalang. It could describe as continual shifting of different interests to use KlikBCA. ease of use of a product is something that is desired by the customer. in theory ease of use according to Davis (1989) to defines ease of use as the degree to which a person believes that information technology (IT) can be easily understood. ease of use will reduce the effort (both time and energy) someone in learning something new, including KlikBCA.

\section{Convenience}

Based on the result of this research indicates that variables of convenience who has significant influence and positive relationship to the interests to use. From the T-test, the significant value of integration is 0.012 which is lower than $\alpha=0.05$ or $5 \%$. If convenience is increasing, the interests to use is also increasing. BCA customers feels that the KlikBCA is flexible in terms of time and place.

\section{Privacy}

Based on the result of this research indicates that the variable of privacy has significant influence to The interests to use. From the T-Test, the significant value of integration is 0.045 which is lower than $\alpha=0.05$ or $5 \%$. The explanation of significance of this variable is that the difference privacy from all BCA customer in area Kalimalang. It could describe as continual shifting of different interests to use KlikBCA. As the proliferation of Internet crime such as account hacking a factor of privacy becomes very important in the use of internet banking in banking transactions. The concept of this trust means that customers trust the reliability of the banks to ensure the safety and privacy customer account. While confidentiality means that all matters relating to the user's personal information confidential, no third party can know.

\section{Feature Availability}

Based on the result of this research indicates that the variable of Feature Availability has no significant influence to The interests to use. From the T-Test, the significant value of integration is 0.953 which is higher than $\alpha=0.05$ or $5 \%$. The explanation of no significance of this variable is that the difference Feature Availability from all BCA customer in area Kalimalang. It could describe as continual shifting of different interests to use KlikBCA. Nowdays as a global era, feature as a equipment for customer interactivity is an important criterion that attract the attention of customers in the delivery of internet banking services. Gerrard and Cunningham (2003) also identified another important factor in the success of e- 
banking, the ability of innovation to address the needs of customers using the feature availability are different on the website.

\section{Conclusions}

Convenience has significant relationship toward the interest to use. It can be shown from the significance value of convenience. Convenience has positive relationship toward the interest to use by looking at the numeric / number of beta. It shows that the relationship of convenience toward the interest to use is positive strong relationship. It shows by the way customers think, feel and act toward a particular aspect of their desire. The value of expressive function is represented by convenience that has been created and serves to express the customers individual values and self-concept. The various functions of convenience lead to the customers overall convenience toward engaging in the given the interest to use, thus influencing behavioral intention. Beside that, ease of use and convenience based on the multiple regression models has significant value toward the interest to use. It can showed from the significant value.

Privacy also has a significant relationship toward the interets to use. It can be shown from the significance value of privacy. Privacy has positive relationship toward the interest to use by looking at the numeric / number of beta. It shows that the relationship of privacy toward the interest to use is positive strong relationship. It shows by the way customers think, feel and act toward a particular aspect of their desire. The value of expressive function is represented by privacy that has been created and serves to express the customers individual values and self-concept. The various functions of privacy lead to the customers overall toward engaging in the given the interest to use, thus influencing behavioral intention.

Based on the multiple regression models, the variable ease of use and feature availability has no significant value toward the interest to use. It can showed from the significant value of ease of use and feature availability. The significance value of ease of use and feature availability not compiled the requirement to become a significant relationship. It shown by the theory. Ease of use and feature availability are not necessarily competence, but it is descriptive of opinions are formed when people evaluate the importance of things they believe to factually correct. Among all of variables, Convenience and privacy is the significant variable toward the interest to use on personal factors of customers to choose using Klik BCA.

\section{References}

Ghozali, Imam, 2006, Aplikasi Analisis Multivariate Dengan Program SPSS, Badan Penerbit Universitas Diponegoro, Semarang.

Tjiptono, Fandi dan Gregorius Chandra. “Service Quality Satisfaction”. Penerbit Andi, Yogyakarta, 2005.

Umar, Husein. “Riset Pemasaran \& Perilaku Konsumen”, Gramedia, Jakarta,2010.

Herawati, Jajuk dan Prayekti, M.Si. "Pengaruh dimensi internet banking service quality dan Kepercayaan nasabah terhadap kepuasan nasabah”. AKMENIKA UPY. 2011. 
Monalisa, Siti dan Erma Suryani. "Pengaruh Kualitas Layanan Internet Banking terhadap Kepuasan dan Loyalitas Nasabah Bank dengan Menggunakan Sistem Dinamik". Institut Teknologi Sepuluh November, Surabaya. 2013.

Saha, Parmita dan Yanni Zhao. "Relationship between Online Service Quality and Customer Satisfaction”. Lulea University Of Technology. 2005.

Vebrika ST, Helza. "Pengaruh Kualitas Jasa Internet Banking Terhadap Kepuasan Konsumen, Thesis. Universitas Gunadarma, 2007.

Zeithaml, et al. "Service Quality Delivery Through Web Sites: A Critical Review of Extant Knowledge", Academy of Marketing Science, 2002.

http://www.bca.co.id/id/about/hubunganmedia/2010_juni_03_bca_raih_dua_penghargaan/20 10_ju ni_03_bca_raih_dua_penghargaan.jsp

http://www.antaranews.com/berita/348186/pengguna-internet-indonesia-2012-capai-63-jutaorang

http://www.merdeka.com/uang/pengguna-online-banking-indonesia-tercepat-diasiatenggara.htm

http://www.bca.co.id/id/about/about_bca_landing.jsp

http://ictwatch.com/id/

http://marsnewsletter.wordpress.com/2008/02/01/klik-bca-dan-m-bca-masihmenjadi-pilihan/ $\underline{\text { www.klikbca.com }}$ 